\title{
Odpowiedzialność pracodawcy i pracownika za szkodę powstałą w bezpośrednim związku z wykonywaniem obowiązków pracowniczych w kontekście ograniczeń zawartych w art. 120 k.p.
}

\section{Employer's and employee's liability for damage arising directly in connection with the performance of employee duties in the context of restrictions contained in Article 120 of the Labor Code}

Tobiasz Nowakowski

Uniwersytet Łódzki, student Wydziału Prawa i Administracji

\begin{abstract}
Streszczenie Zagadnienie dotyczące solidarnej odpowiedzialności pracownika i pracodawcy z tytułu deliktu popełnionego wobec osoby trzeciej wciąż stanowi kwestię nierozstrzygniętą. Dominujący nurt naukowy ostatnich lat przyjmuje, iż wyłączenie odpowiedzialności z art. 120 kodeksu pracy dotyczy jedynie winy nieumyślnej pracownika. Zdaniem autora nie jest to jednak pogląd trafny. Opiera się on bowiem na bardzo niejasnych kryteriach wykładni. Autor uwypuklił szereg wątpliwości, które pojawiają się w kontekście omawianej problematyki.
\end{abstract}

Słowa kluczowe: odpowiedzialność pracodawcy, odpowiedzialność pracownika, czyn niedozwolony, niewykonanie lub nienależyte wykonanie zobowiązania.

Summary The issue of joint and several liability of an employee and employer for a tort committed against a third party is still an unresolved case. The dominant scientific current of recent years assumes that the exclusion of liability under Article 120 of the Labor Code concerns only the negligent of employee. However, this is not a valid view. It is based on very vague criteria for interpretation. The author emphasized a number of doubts that were presented in this article.

Keywords: employee liability, employer liability, tort, non-performance.

JEL: K3

Str. 41-46

\section{Bibliografia}

Askeland, B. (2015). Basic questions of Tort Law from Norwegian perspective. W: H. Koziol (red.), Basic Questions of Tort Law from a Comparative Perspective. Wien, https://doi.org/10.26530/OAPEN_574832.t. LX, nr 6/2019 DOI 10.33226/00326186.2019.6.6

Jankowiak, J. (2012). Glosa do wyroku SN z 27.1.2011 r., II PK 175/10. Orzecznictwo Sądów Polskich, (9).

Kaliński, M. (2014). Szkoda na mieniu i jej naprawienie. Warszawa.

Klein, A. (1979). Przesłanki odpowiedzialności kontraktowej i deliktowej. Studia Iuridica Silesiana, (5).

Koziol, H. (2012). Basic questions of Tort Law from a Germanic perspective. Wien.

Kuźmicka-Sulikowska, J. (2011). Zasady odpowiedzialności deliktowej w świetle nowych tendencji w ustawodawstwie polskim. Warszawa.

Lewaszkiewicz-Petrykowska, B. (1998). Deliktowa odpowiedzialność za własne czyny w prawie cywilnym krajów europejskich. Kwartalnik Prawa Prywatnego, (2).

Liszcz, T. (2012). Prawo pracy. Warszawa. 
Machnikowski, P. (2014). W: A. Olejniczak (red.), System prawa prywatnego. Tom 6. Prawo zobowiązań — częśc ogólna. Warszawa.

Nesterowicz, M. (1989). W: J. Winiarz (red.), Kodeks cywilny z komentarzem. Warszawa.

Nowakowski, T. (2018). Mobbing — czyn niedozwolony czy nienależyte wykonanie zobowiązania. Praca i Zabezpieczenie Spoteczne, (2).

Oliphant, K. (2015). Basic questions of Tort Law from the perspective of England and Commonwealth. W: H. Koziol (red.), Basic Questions of Tort Law from a Comparative Perspective. Wien.

Palmer, V. (2015). W: M. Bussani, A. J. Sebok (red.), Comparative Tort Law: Global Perspective. Cheltenham, Northampton.

Perdeus, W. (2016). W: K. W. Baran (red.), Kodeks pracy. Komentarz. Warszawa.

Piotrowski, W. (2009). Prawo do odszkodowania w świetle norm Kodeksu pracy i Konstytucji RP. W: Z. Góral (red.), Z zagadnień wspótczesnego prawa pracy. Księga jubileuszowa Profesora Henry- ka Lewandowskiego. Warszawa.

Radwański, Z. Olejniczak, A. (2012). Zobowiązania — część ogólna. Warszawa.

Robaczyński, W. Księżak, P. (2012). Niewykonanie lub nienależyte wykonanie zobowiązania jako czyn niedozwolony. W: M. Nesterowicz (red.), Czyny niedozwolone $w$ prawie polskim i prawie porównawczym. Materiały IV ogólnopolskiego Zjazdu Cywilistów, Toruń 2011. Warszawa.

Rylski, M. (2015). Równość i sprawiedliwość w prawie pracy — rozważania na tle art. 120 k.p. Część 2. Praca i Zabezpieczenie Spoleczne, (10).

Skoczyński, J. Pisarczyk, Ł. (2016). W: L. Florek (red.), Kodeks pracy. Komentarz. Warszawa.

Śmieja, A. (2014). W: A. Olejniczak (red.), System prawa prywatne- go. Tom 6. Zobowiąania — część ogólna. Warszawa.

Świątkowski, A. M. (2016). Kodeks pracy. Komentarz. Warszawa.

Ulfbeck, V. (2001). Modern Tort Law and Direct Claims Under the Scandinavian Insurance Acts. W: Tort Liability and Insurances. Scandinavian Studies in Law, (41).

Viney, G. Jourdain, P. Carval, S. (2013). W: J. Ghestin (red.), Les conditions de la responsabilite. Paris.

Wagner, B. (2004). W: B. Wagner (red.), Kodeks pracy. Komentarz. Gdańsk.

Warkałło, W. (1970). Gradacja winy a obowiązek naprawienia szkody w świetle Kodeksu cywilnego. Studia Prawnicze, (26-27).

Warkałło, W. (1972). Odpowiedzialność odszkodowawcza. Funkcje. Rodzaje. Granice. Warszawa.

Więzowska, B. (2009). Odpowiedzialność cywilna na zasadzie stuszności. Warszawa.

Zawistowski, D. (2000). Powstanie i cechy zobowiązań in solidium. W: E. Gniewek (red.), O źródłach i elementach stosunków cywilnoprawnych. Księga pamiątkowa ku czci Profesora Alfreda Kleina. Zakamycze.

Zoll, F. (2011). W: A. Olejniczak (red.), System prawa prywatnego. Tom 6. Suplement. Warszawa.

Zoll, F. (2014). W: A. Olejniczak (red.), System prawa prywatnego. Tom 6. Prawo zobowiązań-część ogólna. Warszawa. 